\title{
Study on Calculation Method of Target Ecological Water Amount in Shortage Areas of Mintuo River Basin
}

\author{
Tang Bing ${ }^{1, *}$, Li Bo $^{1}$, and Wang WenChao ${ }^{1}$ \\ ${ }^{1}$ Changjiang Institute of Survey, Planning, Design and Research, Wuhan, Hubei ,China
}

\begin{abstract}
Ecological water replenishment is the part of ecological flow deducting the remaining local existing water that needs to be recharged by other water sources. It has become the basic basis for water resources development and utilization and water affairs coordination. Ecological flow is a complex concept with numerous calculation methods and obvious regional differences. In view of the characteristics of the Mintuo River Basin, especially the problem that the extensive economic development exceeds the environmental carrying capacity of the river, considering the lack of natural rainfall, this paper recommends a one-dimensional water quality simulation method that maintains environmental capacity. Taking Jingyan County as a representative, a case study was carried out. The river was divided into several sections according to the water function zoning, and the water quality of each section was simulated to determine the section and the total river water replenishment, and through compared with the traditional calculation method of water conservancy planning, the rationality and benefit of the period are analyzed.
\end{abstract}

\section{Introduction}

The focus of the calculation of ecological water replenishment in rivers is to calculate the ecological flow. Ecological flow is an important indicator to ensure the ecological functions of rivers and lakes, and is an important basis for coordinating life, production and ecological water use, and optimizing the allocation of water resources.[1] It is related to regional water security and the healthy development of economic society. Defining a reasonable ecological flow is not only a requirement for current water resources management and control, but also a basis for supporting the rational development of the economic society of the area. Ecological flow is a complicated concept. At present, there is no clear and unified definition at home and abroad. Due to different research focuses and goals, there are still a lot of different appellations. For example, the European Union's "Water Framework Directive" is called Ecological Flow, the International Conference on Environmental Flows "Bruceban Declaration", and The Nature Conservancy is called Environmental flow is called river ecological water consumption, ecological base flow, basic ecological environmental water demand, and water ecological base flow in different fields such as environmental protection, water conservancy, and energy in China. In recent years, after a lot of discussion, integration and practice, the domestic concept of ecological flow has gradually reached a consensus. It is generally believed that the connotation of ecological flow considers the maintenance of the ecological function of the river and the protection of the healthy economic and social development. It can be divided into basic ecological flow and target ecological flow. Basic ecological flow refers to the minimum amount of water and process that needs to be retained in rivers, lakes and marshes to maintain the structure and function of rivers, lakes, swamps, and ecosystems; the target ecological flow is the normal use of rivers, lakes, and marshes Eco-environmental goals need to retain the flow in the river, which basically forms a consensus.

However, the calculation of ecological flow is still controversial. At present, there are more than 200 kinds of calculation methods for ecological flow at home and abroad [3], mainly hydrology method, hydraulic method, habitat simulation method and overall analysis method. The more typical hydrological methods are Tannant method, Q90 method, flow duration curve method, hydraulic method is typically R2-Cross method, wet cycle method, etc., habitat simulation method is typically water quality simulation method, IFIM method, etc., analysis methods include BBM method, DRIFT method, etc.

However, there are significant differences between regions in China. The level of economic and social development, hydrogeographical types, water resources endowments, and ecological function positioning are different. How to choose a calculation method is an extremely difficult problem, and statistical calculation methods are not suitable. If a unified ecological flow calculation method is adopted, it will inevitably cause the water ecological environment in some more sensitive areas to continue to deteriorate. For this reason, some scholars have put forward suggestions on ecological flow by zoning and classification. For example, Hai River 4 and

Corresponding author: ${ }^{\mathrm{a} d u m m y t b @ 163 . c o m ~}$ 
Huai River 5 have proposed calculation suggestions and safeguard measures for ecological flow in their respective basins.

The Mintuo River Basin studied in this article is located in the central part of Sichuan Province. It has a special location, a large population, a developed industry, a concentrated population of cultivated land, and a prominent regional and seasonal water shortage. According to the statistics of the five major water systems in Sichuan, the water quality compliance rate of the main stream of the Yangtze River (Sichuan section), the main stream of the Jinsha River, and the main stream of the Jialing River are all $100 \%$, while the water quality compliance rate of the main streams of the Min River and Tuo River are only $46.2 \%$ and $13.3 \%$, respectively. The focus of water-saving environmental improvement, but the improvement of its water quality is extremely difficult. Practice has shown that it is difficult to achieve the desired effect through some general measures such as local pollution interception and drainage of ecological base flow from reservoirs. Aiming at the above problems, this paper adopts an idea of improving the water body's pollution holding capacity, using a one-dimensional hydrodynamic model to simulate the water quality process and calculate the ecological water demand. Taking Jingyan County in the transition zone of the Mintuo River as an example, a typical case study was carried out.

\section{Materials and Methods}

\subsection{Overview of the study area}

Jingyan County is a county under the jurisdiction of Leshan City, Sichuan Province. It is located in the southwest of Sichuan Basin, with Renshou in the north, Rong County in the east, Qianwei and Wutong Bridge in the south, the central district of Leshan City in the west, and Qingshen in the northwest. It covers an area of $840 \mathrm{~km}^{2}$, which occupies $6.6 \%$ of the Leshan city. Jingyan County is located in the central area of Leshan Town and the core economic zone of Leshan. It is an important channel for Leshan City to merge into Chengdu. It will become a first-level sub-central city of Leshan City, with good location advantages and development prospects.

Mangxi River is a first-level tributary on the left bank of the lower reaches of the Minjiang River. It runs through the entire Jingyan area from north to south and is the most important river in Jingyan County. The average precipitation depth in Jingyan County for many years is $963.8 \mathrm{~mm}$, and the county's per capita water resources are $1352 \mathrm{~m}^{3}$, which is only $38 \%$ of the per capita water resources of Leshan City. The current water resources development utilization rate reaches $32 \%$, which is close to the sustainable development utilization rate of water resources. The upper limit is a severe resource shortage area; at the same time, the water volume of the Mangxi River Basin is unevenly distributed during the year, and the runoff during the dry season (November to the next 4 years) accounts for only $13 \%$ of the entire year. The precipitation time is uneven Sex has further exacerbated the contradiction between water supply and demand. In addition, the long-term use of production and domestic water has squeezed the ecological water of the river, resulting in a serious shortage of water in the dry season of the river, deterioration of water quality, and a water shortage problem. At the same time, Jingyan County's poor water resources endowment conditions have become increasingly prominent in contradiction with the healthy development of the society and economy. The bearing pressure on resources and the environment is increasing. The local water resources conditions cannot support the healthy development of the local economy and society, and water must be transferred from outside the region to solve the problem of water shortage in Jingyan County.

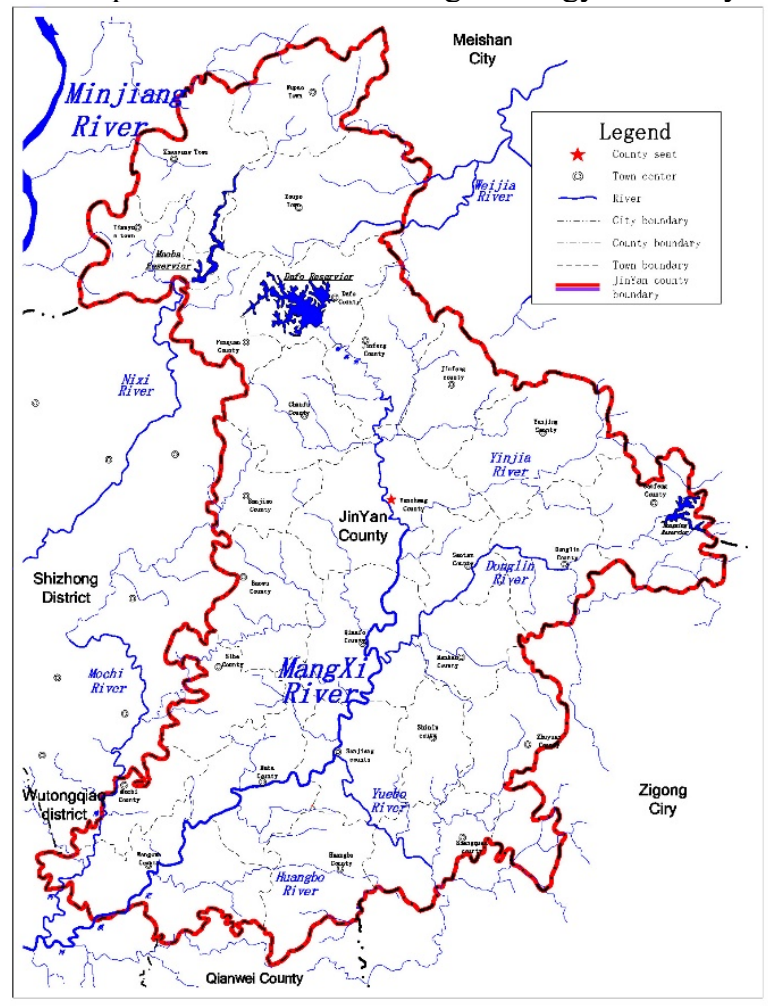

Figure 1 Water system of Jingyan County

\subsection{Calculation unit}

The Jingyan section of the Mangxi River involves 3 water function zones. The Mangxi River is divided into three sections, namely, Jingyan Reserve, Jingyan Development and Utilization Zone, and Jingyan Wutongqiao Reserve with the water function zone as the boundary; The nodes (involving Dafo Town, Jinfeng Town, Yancheng Town, Qianfo Town, Sanjiang Town, Mata Town and Wangcun Town) are divided into 7 river sections; finally, considering the main tributaries and important sewage outlets as nodes, the Mangxi River Divided into 19 river sections, as shown in Table 1.

Table 1 Calculation section table of Mangxi River

\begin{tabular}{|c|c|c|}
\hline Section & $\begin{array}{c}\text { Owned water } \\
\text { function area }\end{array}$ & Town \\
\hline Dafo Town Entry-Town & Mangxi River & Dafo Town \\
\hline
\end{tabular}




\begin{tabular}{|c|c|c|}
\hline Exit & \multirow[t]{7}{*}{ Jingyan Reserve } & \\
\hline Jinfeng Town Entry-Town & & \multirow[t]{2}{*}{ Jinfeng Town } \\
\hline Exit & & \\
\hline Yancheng Town Entry-Sai & & \multirow[t]{4}{*}{ Yancheng town } \\
\hline Gong River & & \\
\hline \multirow{2}{*}{$\begin{array}{c}\text { Saigong River-Xiajiaqiao } \\
\text { Section }\end{array}$} & & \\
\hline & & \\
\hline Xiajiaqiao Section- & \multirow{14}{*}{$\begin{array}{l}\text { Mangxi River } \\
\text { Jingyan } \\
\text { Development } \\
\text { and Utilization } \\
\text { Zone }\end{array}$} & \multirow[t]{6}{*}{ Yancheng town } \\
\hline Yinjiahe & & \\
\hline Yinjiahe-Sewage & & \\
\hline Treatment Plant & & \\
\hline Sewage Treatment Plant- & & \\
\hline Yancheng Outbound & & \\
\hline Qianfo Town Entry-Food & & \multirow{6}{*}{ Qianfo Town } \\
\hline Food Factory-Qianfo & & \\
\hline Sewage Ireatment Plant & & \\
\hline $\begin{array}{c}\text { Qianfo Sewage Plant- } \\
\text { Donglin River }\end{array}$ & & \\
\hline \multirow[t]{2}{*}{ Donglin River-Qianfo } & & \\
\hline & & \\
\hline \multirow{2}{*}{\multicolumn{2}{|c|}{ Sanjiang Town Entry- }} & \\
\hline & & \\
\hline Sanjiang Town Section- & \multirow{15}{*}{$\begin{array}{l}\text { Mangxi River } \\
\text { Jingyan Wutong } \\
\text { Bridge Reserve }\end{array}$} & \multirow{7}{*}{$\begin{array}{l}\text { Sanjiang Town } \\
\text { Sanjiang Town }\end{array}$} \\
\hline Yuebo River & & \\
\hline Yuebo River-Sanjiang & & \\
\hline Wastewater Treatment & & \\
\hline Plant & & \\
\hline Sanjiang Sewage & & \\
\hline Treatment Plant-Town Exit & & \\
\hline Entry in Mata Town-Town & & \\
\hline Sewage Outlet & & \\
\hline Mata Town Sewage & & \\
\hline Outlet-Outbound & & \\
\hline Wangcun Town Entry- & & \\
\hline Town Sewage Outlet & & \\
\hline Wangcun Town Sewage & & \\
\hline Outlet-Town Exit & & \\
\hline
\end{tabular}

\subsection{Data collection and processing}

\subsubsection{Mangxi River Hydrological Data}

Mangxi River is a primary tributary on the left bank of the lower reaches of the Minjiang River. It is the main river in Jingyan County and the upper reaches is called Yanxi River. Originated in Laoyashan, Dafo Town, Jingyan County, the mainstream spans, Jingyan County,
Wutongqiao District, and merges into Minjiang Chahe Yongsijiang at Siwangguan, Zhugen Town, Wutongqiao District, Leshan City, with an elevation of $352.0 \mathrm{~m}$. The drainage area is $1238 \mathrm{~km}^{2}$, the main stream is $95.0 \mathrm{~km}$ in length, and the annual average runoff is 582 million $\mathrm{m}^{3}$; in Jingyan County, the area is $663 \mathrm{~km}^{2}$, the river length is $75.0 \mathrm{~km}$, and the annual average runoff is 300 million $\mathrm{m}^{3}$.

In the Mangxi River Basin, Jingyan Hydrological Station and Qianfo Hydrological Station have been set up in Yancheng Town and Qianfo Town of Jingyan County, and there are hydrological data of a short period of time. Xinglong (II) Hydrological Station is located on the Weiyuan River in the nearby basin. However, due to the short period of hydrological observation data at Jingyan Station, there is no other station to interpolate and extend, the quality is poor, the water level change is small, and its representativeness is also insufficient, and it is not suitable for calculation basis and can only be used for reference; Qianfo Hydrological Station has the flow data in 1963 1964 and the measured data have a short life span, which is difficult to use in engineering. The Xinglong (II) Hydrological Station is located on the Weiyuan River in the adjacent basin, and its climate and underlying surface conditions are similar to those of the Mangxi River Basin, which can be used as the basis for this hydrological analysis and calculation.

The hydrological analogy method was used to calculate the runoff of various stations along the Mangxi River from 1988 to 2017.

Table 2 Mangxi River Natural Inflow Table

\begin{tabular}{|c|c|c|c|c|}
\hline \multirow{2}{*}{$\begin{array}{c}\text { Exit section of } \\
\text { administrative area }\end{array}$} & \multicolumn{4}{|c|}{ Average annual flow of different incoming } \\
& & & \multicolumn{4}{|c|}{ water frequency $\left(\mathrm{m}^{3} / \mathrm{s}\right)$} \\
\cline { 2 - 5 } & $25 \%$ & $50 \%$ & $75 \%$ & $95 \%$ \\
\hline Dafo Town & 0.41 & 0.35 & 0.31 & 0.27 \\
\hline Jinfeng Town & 0.81 & 0.70 & 0.61 & 0.53 \\
\hline Research town & 6.19 & 5.40 & 4.24 & 3.65 \\
\hline Qianfo Town & 6.83 & 5.96 & 4.73 & 4.06 \\
\hline Sanjiang Town & 7.00 & 6.10 & 4.86 & 4.17 \\
\hline Mata Town & 7.65 & 6.66 & 5.35 & 4.59 \\
\hline Wangcun Town & 9.07 & 7.91 & 6.43 & 5.52 \\
\hline
\end{tabular}

\subsubsection{Point source pollution source}

According to the survey results of the "One River, One Policy" Management and Protection Plan for the Mangxi River Basin, the main sewage outlets in the main stream of the Mangxi River are distributed in Yancheng Town, Qianfo Town, Sanjiang Town, Mata Town, Wangcun Town, and there are 20 places above designated size. , Including 10 domestic sewage outlets and 10 industrial sewage outlets. The largest is the sewage outlet of the Jingyan County Urban Domestic Sewage Treatment Plant. This point source emission scenario is arranged in accordance with the current annual pollution discharge 
outlets, and according to the relevant planning economic and social development forecast emission data in 2030, the emission standards uniformly implement the "Sichuan Province Minjiang and Tuojiang River Basin Water Pollutant Discharge Standards" (DB51/2311-2016), COD concentration limit is $30 \mathrm{mg} / \mathrm{L}$, ammonia nitrogen concentration (calculated in nitrogen) limit is $1.5 \mathrm{mg} / \mathrm{L}$. The point source emissions are shown in Table 3.

Table 3 Summary of point source discharge of Mangxi River

\begin{tabular}{|c|c|c|c|}
\hline $\begin{array}{c}\text { Administrative } \\
\text { District }\end{array}$ & $\begin{array}{c}\text { Waste water } \\
\left(\times 10^{4} \mathrm{~m}^{3}\right)\end{array}$ & $\operatorname{COD}(\mathrm{t} / \mathrm{a})$ & $\begin{array}{c}\text { Ammonia - } \\
\text { nitrogen }(\mathrm{t} / \mathrm{a})\end{array}$ \\
\hline Dafo Town & 5.23 & 1.57 & 0.08 \\
\hline Jinfeng Town & 3.70 & 1.11 & 0.06 \\
\hline Research town & 331.98 & 99.59 & 4.98 \\
\hline Qianfo Town & 53.05 & 15.91 & 0.80 \\
\hline Sanjiang Town & 5.27 & 1.58 & 0.08 \\
\hline Mata Town & 59.67 & 17.90 & 0.89 \\
\hline Wangcun \\
Town
\end{tabular}

\subsubsection{Non-point source pollution source}

Non-point sources include five aspects: urban life, rural life, farmland runoff, aquaculture, and livestock and poultry farming. The calculation method is the same as that of point sources, and the economic and social development data forecast in 2030 is used in the relevant planning.

(1) Urban life The non-point source of urban life is the area not covered by the sewage treatment plant pipeline network. According to the "Jingyan County Urban Master Plan (2015-2030)", all urban life will be included in the sewage pipeline network in 2020 . Therefore, there is no point source of urban life in planning level year.

(2) The emission quotas of various pollution sources for rural life, farmland runoff, aquaculture, and livestock and poultry breeding shall be calculated in accordance with the values given in the National Water Environment Technology Verification Guide. The coefficient of entering the river adopts related research results such as "Accounting and Source Analysis of Pollution Load at Cuntan Section of the Main Stream of the Yangtze River", using the following formula:

$$
r=\left\{\begin{array}{lr}
0.1 \times\left(\frac{p}{\bar{p}}\right) & \text { flood season } \\
\min \left[0.1 \times\left(\frac{p}{\bar{p}}\right)^{2.0}\right. & , 0.01] \text { Non }- \text { flood season }
\end{array}\right.
$$

Among them, $r$ is the river entrance coefficient, $\mathrm{p}$ is the annual rainfall, and $\bar{p}$ is the multi-year average rainfall in $\mathrm{mm}$. Rainfall uses data from Jingyan Rainfall Station. After calculation, the non-point source inflow coefficient is 0.15 . How to measure the non-point source is shown in Table 4.

Table 4 Summary of Mangxi River's non-point source inflow

\begin{tabular}{|c|c|c|c|}
\hline $\begin{array}{c}\text { Administrative } \\
\text { District }\end{array}$ & $\begin{array}{c}\text { Waste water } \\
\left(\times 10^{4} \mathrm{~m}^{3}\right)\end{array}$ & $\operatorname{COD}(\mathrm{t} / \mathrm{a})$ & $\begin{array}{c}\text { Ammonia - } \\
\text { nitrogen }(\mathrm{t} / \mathrm{a})\end{array}$ \\
\hline
\end{tabular}

\begin{tabular}{|c|c|c|c|} 
Dafo Town & 8.28 & 27.16 & 2.77 \\
\hline Jinfeng Town & 6.53 & 25.06 & 2.60 \\
\hline Research town & 337.91 & 149.07 & 10.28 \\
\hline Qianfo Town & 56.10 & 42.04 & 3.75 \\
\hline $\begin{array}{c}\text { Sanjiang Town } \\
\text { Mata Town }\end{array}$ & 6.21 & 9.34 & 0.95 \\
\hline $\begin{array}{c}\text { Wangcun } \\
\text { Town }\end{array}$ & 34.27 & 33.99 & 3.26 \\
\hline
\end{tabular}

\subsection{Calculation method}

\subsubsection{Governing equation}

In this paper, the water balance method based on the onedimensional river water quality model is adopted. In order to simplify the calculation, two control equations are used in each calculation area in this paper. The complete mixed model is used at the starting point of each calculation partition:

$$
C_{i}=\frac{C_{m} \cdot Q_{m}+C_{p} \cdot Q_{p}+C_{b} \cdot Q_{b}+W++C_{i n} \cdot Q_{i n}}{Q_{m}+Q_{p}+Q_{b}+Q_{i n}}
$$

In the formula, $\mathrm{Ci}$ is the concentration of pollutants in the initial section of the calculation zone, in $\mathrm{mg} / \mathrm{l}$, and $\mathrm{Cm}$ and $\mathrm{Qm}$ are the concentration and flow of pollutants flowing into the unit from the upstream computing unit, and the units are $\mathrm{mg} / \mathrm{l}$ and $\mathrm{m}^{3} / \mathrm{s}$ respectively, the same below, $\mathrm{Cp}$ and $\mathrm{Qp}$ are the concentration and flow of pollutants flowing into the unit by the tributaries, $\mathrm{Cb}$ and $\mathrm{Qb}$ are the concentration and flow of pollutants flowing into the unit from point sources, and $\mathrm{W}$ is the flow into the river from non-point sources, in $\mathrm{g} / \mathrm{s}$. Cin and Qin are the pollutant concentration and flow of the external diversion water into this unit. In this paper, it is assumed that the Mangxi River draws water from the neighboring Minjiang River. Cin is the water quality of the Minjiang River in 2030, COD is $10 \mathrm{mg} / \mathrm{L}$, ammonia nitrogen is $0.5 \mathrm{mg} / \mathrm{L}$, and Qin is To meet the trial calculation value of $\mathrm{Ci}$ not exceeding the standard, in our calculation, the $\mathrm{Ci}$ is limited, COD is $20 \mathrm{mg} / \mathrm{L}$, and ammonia nitrogen is $1 \mathrm{mg} / \mathrm{L}$.

After the pollutants are fully mixed in the initial section, the pollutants are degraded when flowing along the river. A one-dimensional degradation model is adopted:

$$
C_{i+1}=C_{i} \cdot e^{(-k \cdot t)}
$$

In the formula, $\mathrm{C}_{\mathrm{i}+1}$ is the final section concentration of the calculation unit, $\mathrm{k}$ is the degradation coefficient, unit is $\mathrm{d}$, refer to the relevant calculation results of Jingyan County, and take 0.1 ; $\mathrm{t}$ is the flow time of the pollutant in the calculation unit, unit is $\mathrm{s}$, taking $\mathrm{t}=\mathrm{L} / \mathrm{V}$ in calculation, $\mathrm{L}$ is the length of the calculation unit, and $\mathrm{V}$ is the average flow rate.

\subsubsection{Calculation steps}

Two indicators of COD and ammonia nitrogen were selected, in accordance with the water quality requirements of the water function zone, so that the water quality of the Mangxi River after replenishment reached the surface water level III requirements, and the threshold 
values of COD and ammonia nitrogen were $20 \mathrm{mg} / \mathrm{L}$ and $1.0 \mathrm{mg} / \mathrm{L}$, respectively. The tributaries are generalized as point source sewage outlets, and the water quality is considered to meet the standard class III. At the same time, it is considered that the river sediment has been treated and no new pollutants are released into the water body.

The calculation steps are: starting from the most upstream sewage outlet of the first river section, using a one-dimensional water quality simulation model to calculate each sewage outlet in turn until the end of the river section; determine whether the water quality of the downstream end of the river section meets the surface water quality requirements of Class III. If it meets the requirements, calculating the next river section; if it does not meet the requirements, trying to calculate the water supply of the Minjiang River until the water quality of all sections meets the surface water quality requirements of Class III.

\section{Results \& Discussion}

\subsection{Simulation results of typical years}

In this paper, the monthly ecological flow from 1988 to 2017 was calculated, and the ecological water replenishment after deducting the background flow of the river was calculated. Table 5 lists the calculation results of 4 typical years, and selected $25 \%, 50 \%, 75 \%$, and $95 \%$ of the incoming water years to represent the four types of years of high, flat, dry, and extremely dry. There is a big difference between the annual and monthly ecological water requirements. The amount of ecological water replenishment in extremely low water years can reach 2.4 times that of wet years, and the amount of ecological water replenishment in dry months can reach more than 6 times that of wet months.

Figure 6 lists the changes in the ecological water demand along the river under the average conditions for many years. The ecological water supply has increased sharply in the outlet section of the research town, which is closely related to the pollution caused by urban development.

Table 5 he average annual water supply for each section

\begin{tabular}{|c|c|c|c|c|}
\hline \multirow{2}{*}{ Frequency } & \multicolumn{4}{|c|}{ Ecological water supply $\left(\times 10^{4} \mathrm{~m}^{3}\right)$} \\
\cline { 2 - 5 } & $25 \%$ & $50 \%$ & $75 \%$ & $95 \%$ \\
\hline January & 132 & 118 & 234 & 240 \\
\hline February & 261 & 285 & 209 & 294 \\
\hline March & 262 & 265 & 318 & 430 \\
\hline April & 127 & 340 & 363 & 433 \\
\hline May & 63 & 55 & 317 & 464 \\
\hline June & 37 & 84 & 112 & 437 \\
\hline July & 45 & 60 & 79 & 500 \\
\hline August & 52 & 42 & 170 & 438 \\
\hline September & 197 & 348 & 182 & 445 \\
\hline October & 103 & 346 & 353 & 376 \\
\hline
\end{tabular}

\begin{tabular}{|c|c|c|c|c|}
\hline November & 325 & 298 & 318 & 339 \\
\hline December & 306 & 296 & 282 & 242 \\
\hline Total & 1910 & 2535 & 2936 & 4637 \\
\hline
\end{tabular}

Table 6 The average annual water supply for each section

\begin{tabular}{|c|c|c|}
\hline $\begin{array}{l}\text { Control } \\
\text { project: }\end{array}$ & $\begin{array}{c}\text { Export section of } \\
\text { Town } \\
\end{array}$ & $\begin{array}{l}\text { Ecological water supply } \\
\qquad\left(\times 10^{4} \mathrm{~m}^{3}\right)\end{array}$ \\
\hline \multirow{7}{*}{$\mathrm{COD}$} & Dafo Town & 359 \\
\hline & Jinfeng Town & 588 \\
\hline & Research town & 947 \\
\hline & Qianfo Town & 1082 \\
\hline & Sanjiang Town & 1082 \\
\hline & Mata Town & 1277 \\
\hline & Wangcun Town & 1334 \\
\hline \multirow{7}{*}{$\begin{array}{l}\text { Ammonia } \\
\text { nitrogen }\end{array}$} & Dafo Town & 202 \\
\hline & Jinfeng Town & 243 \\
\hline & Research town & 1048 \\
\hline & Qianfo Town & 1664 \\
\hline & Sanjiang Town & 1731 \\
\hline & Mata Town & 2313 \\
\hline & Wangcun Town & 2664 \\
\hline
\end{tabular}

\subsection{Comparison with calculation results of traditional methods}

In this paper, the one-dimensional water quality simulation method was used to calculate the ecological flow and ecological water demand of the river through the analysis of the pollution holding capacity. The calculated multi-year average ecological water demand of the Mangxi River in Jingyan County is 26.64 million $\mathrm{m}^{3}$. At the same time, using the Tennant method commonly used in Sichuan Province, taking 15\% of the average flow for many years, the average water demand of the Mangxi River for many years is calculated as 9.8 million $\mathrm{m}^{3}$. The comparison between the two shows that the calculation result of the one-dimensional water quality simulation method is significantly greater than that of the traditional Tennant method, the former is about 2.7 times the latter. The one-dimensional water quality simulation method reflects the insufficient carrying capacity of the Mintuo River Basin.

\section{Conclusions}

The Mintuo River Basin in Sichuan Province is a dry and water-deficient area. The rapid development of urbanization has caused the problem of insufficient water environment carrying capacity. This paper proposes a onedimensional water quality simulation method to calculate the ecological flow and ecological water demand of the river from the perspective of maintaining the self- 
purification capacity of the river, and establishes a set of calculation methods to be applied to the Mangxi River in Jingyan County to calculate the multi-year average ecological demand of the Mangxi River. The water volume is 26.64 million $\mathrm{m}^{3}$, which is about $9 \%$ of the natural runoff of the Mangxi River, which is higher than the calculation result of the traditional tenant method and reflects the pressure on the ecological environment of the river channel from water outside the river.

Through theoretical calculations, the ecological water demand proposed in this paper can ensure that the Mangxi River reaches Class III water quality in 2030, while supporting regional economic development. The calculation method is more suitable for the characteristics of the Mintuo River Basin. However, there are no practical cases of this method at present, but it has been suggested to the local government that with the help of the Minmang connection project to be implemented in Jingyan County, the effect of this method can be further verified in the future and provide reference cases for similar areas.

\section{Acknowledgments}

This paper is one of the phased achievements of The National Key Research and Development Project --
Technology and Application of Water Resources Dispatching for Complex River-lake-connected Areas in the Yangtze River Delta (2016YFC0401506).

\section{References}

1. Lin Yuqing,Chen Qiuwen.(2020), The study on relevant issues of ecological flow assurance .J. China Water Resources, 15:26-29,19.

2. Li Yuanyuan, Liao Wengen, Zhao Zhongnan, Xing Ziqiang, Zhang Yue, Wang Ding(2019). China Water Resources, 17:13-16,8.

3. Dong Zheren, Zhang Jing, Zhao Jin yong, Scientific connotation of ecological flow .J. China Water,15:1519

4. Tian You (2020) Discussion on ecological flow guarantee and impelling countermeasure of the Haihe River Basin .J. China Water Resources, 15:50-52

5. Gu Hong (2020) Analysis of key points and Difficulties in determining and guaranteeing the ecological flow of rivers and lakes in Huai River Basin.J. China Water Resources, 15: 47-49 